\title{
Algae and their Mode of Life in the Baradla Cave at Aggtelek II \\ By George Chaus ${ }^{1}$ )
}

With plates $6(1)-8(3)$

On page 16 of our publication which apperared in 1955 (1) we published a table concerning algae which we collected in the cave of Aggtelek, cultured on sun light, returned them into the cave and reexamined after six months. Already in this publication we pointed out that we did not remove the entire algal material from the cave since it was our intention to carry out a further control examination after another six months. (Unfortunately, we could not quite adhere to the planned six months interval and investigation of the material in the jars could only be carried out after approximately eight months.)

In the following we will briefly summarize the dates on which examinations in the cave were carried out.

On July 11, 1953 we made the first collection. The material which came from this collection and which was then cultured on sun light was returned into the cave on June 22, 1954 at the following three places:

First jar: Around the center of Nádor Street, on the left side, where the path broadens, in a groove of the wall, in a height of about $2 \mathrm{~m}$.

Second jar: Further down on the left side of Nádor Street, about $15 \mathrm{~m}$. after the first projection, at the back of a large stalactite, in a height of $2.5-3 \mathrm{~m}$.

Third jar: Before the end of Nádor Street, on the left side, at the second projection, after the terrace, in a groove of the wall, at a height of $2 \mathrm{~m}$.

(Consequently, all three jars were placed at a distance of 5-600 m. from the entrance.)

On December 12, 1954 we took the first samples from the glass dishes. The above mentioned table (1955.p.16.) contains the species we retrieved at the time.

On October 13, 1955 we removed the glass boxes for the last time. At this occasion, we carefully wrapped the jars in black paper and kept

\footnotetext{
1) New York University-Medical Center.
} 
them that way until we carried out the control tests to prevent their being exposed to light. The algae which thus turned up at the occasion of identification had therefore been 17 months, from June 22, 1954 until October 13, 1955 in the cave in complete darkness. The enclosed photos show our jars after they had been brought up from the cave. It can be seen from these photos that the algal material kept its hue in the past time interval; and the microscopical examinations show that our algae weathered out the past time period not in the form of spores or cysts leading a latent life. Although no proliferation on large scale took place they nevertheless kept their original consistency. That despite the long period of darkness no degenerative processes took place we were able to prove by exposing our cultures again to sun light and, in consequence, our algae in the glass boxes began to proliferate on large scale and formed abundant cultures. At the occasion of our next control test in December 1957 we were again able to recognize the species we had in October 1955.

We wish to point out as an interesting fact that we filled up our cultures during these four years only three times with sterile Knopp solution and only once, in June 1954, at the time of returning the algae to the cave, with water from the brook of the cave. Above fact greatly reduces the possibility of the hitherto known chemosynthetic processes concerning the assimilation of the algae in the jars. After closing our tests, in January 1958, we prepared exiccata from our cultures.

In the following table we summarize the results obtained concerning the three jars:

As can be seen from the above table, we originally replaced 31 species in the cave. From these we succeeded after 6 months to determine 22 and after another 8 months only 13. The apparent loss is therefore 18 species which is to be attributed mainly to the Cyanophyta and the filamentous Chlorophyta. This loss, however, is therefore a seeming one because in December, 1957, i.e. at the time when the control test was carried out, after culturing on sun light we again succeeded in finding 4 species which did not appear at the time of our preceding determination. It is therefore obvious that also in 1954 and 1955 respectively, they had to be present in the material and escaped our attention only because of their small number.

Plectonema puteale, Phormidium henningsii, Schizothrix fragilis, Fragilaria virescens and Tetraspora tarnayana were the species which we did not succeed in finding in any of our redeterminations.

Finally, we would like to mention that at the occasion of all three determinations Synechococcus elongatus, Phormidium dimorphum, 
Table

\begin{tabular}{ccccccc}
\hline & \multicolumn{3}{c}{ Number of jar } & \multicolumn{3}{c}{ Redetermination } \\
Species & & & 1954 & 1955 & 1957 \\
& I & II & III & XII. & X. & XII. \\
\hline
\end{tabular}

\section{GYANOPHYTA}

Synechococcus elongatus

Plectonema puteale

Nostoc punctiforme

Spirulina laxa

Pseudanabaena tenuis

Oscillatoria tenuis

Oscillatoria neglecta

Oscillatoria limnetica

Oscillatoria geminata

Oscillatoria agardhii

Phormidium foveolarum

Phormidium henningsii

Phormidium dimorphum

Lyngbya diguetii

Lyngbya martensiana

Schizothrix fragilis

Schizothrix cyanea

\section{CHRYSOPHYTA}

Ophyocythium parsulum Ochromonas ovalis

Fragilaria virescens

Navicula mutica var. nivalis

Nitzschia thermalis

$\begin{array}{cccccc} & & + & + & + & + \\ + & & + & & & + \\ + & & & + & & + \\ & & + & + & + & + \\ & + & & + & & + \\ & + & & & & + \\ + & & + & + & + & + \\ & & + & + & + & + \\ & & & + & & \\ & & + & & & \\ & + & + & + & + \\ & & + & & \\ & + & + & & \\ & & + & & \end{array}$

\section{CHLOROPHYTA}

Gloeococcus schröterii

Tetraspora tarnayana

Chlorococcum infusionum

Chlorella miniata

Oocystis pusilla

Protococcus anulatus

Hormidium flaccidum

Stichococcus bacillaris $f$. minor

Rhizoclonium hieroglyphicum

Total: 
Gloecoccus schröterii, Chlorococcum infusionum, Chlorella miniata and Protococcus anulatus appeared with the largest number, in other words mostly Chlorophyta and not Cyanophyta as was expected. We cannot give any explanation for this fact. However, Suba (2) directs the attention to a similar circumstance in her publication concerning the examinations carried out on algae of the Cave of Pálvölgy. The author succeeded in finding numerous Chlorophyta from the most hidden points of the cave while from places relatively nearer to the entrances she discovered mostly Cyanophyta. Evidently, we cannot draw conclusions from these two data, however, they seem to point to the fact that the very primitive Chlorophyta are more able to endure lack of light than some filamentous Cyanophyta.

\section{SUMMARY}

The author provides additional data to his publication of 1955. In a table he shows his results concerning 31 algal species which were returned to the cave of Aggtelek on June 22, 1954. When carrying out his control tests he found the decrease in the number of species to be 9 after 6 months and 18 after a further 8 months. In December 1957, after culturing on sun light however he was able to show again the presence of 17 species, but in his cultures Synechoccus elongatus, Phormidium dimorphum, Gloecoccus schröterii, Chlorococcum infusionum, Chlorella miniata and Protococcus anulatus, appeared with the largest individual numbers and not the Cyanophyta as could have been expected.

\section{ZUSAMMENFASSUNG}

Der Verfasser stellt zusätzliche Angaben zu seiner Arbeit von 1955 zur Verfügung. In einer Tabelle führt er seine Ergebnisse bezüglich 31 Algenarten an, welche am 22. Juni 1954 in die Aggteleker Höhle zurückgebracht wurden. Bei Durchführung seiner Kontrolluntersuchungen fand er, daß die Anzahl der Arten nach 6 Monaten um 9 und nach weiteren 8 Monaten um 18 abnahm. Im Dezember 1957, nach Züchten bei Sonnenlicht war es dem Verfasser möglich, wieder die Gegenwart von 17 Arten aufzuweisen, doch erschienen in seinen Züchtungen anstatt der Cyanophyta, wie erwartet, die Synechoccus elongatus, Phormidium dimorphum, Gloecococcus schröterii, Chlorococcum infusionum, Chlorella miniata und Protococcus anulatus mit der größten Anzahl.

\section{REFERENCES}

1. Craus, G. - 1955: Algae and Their Mode of Life in the Baradla Cave at Aggtelek. Acta. Bot. Acad. Sci. Hung. 2:1-26.

2. Su в A, E. - 1957: Angaben zur Algenflora des Pálvölgyer Höhle in Ungarn. Verh. Öster. zool.-bot. Ges., Wien 97:97-110. 


\section{EXPLANATION OF PLATES}

\section{PLATE I}

1. First jar: (Somewhat smaller than actual size.)

2. First jar: The bark-like, dark, greenish-blue algal coating covering the stalactite is well visible. Upwards from the end of the stalactite thalli of Oscillatoria geminata and Chlorococcum infusuonum. (Somewhat larger than normal size.)

\section{PLATE II}

1. Second jar: (Somewhat smaller than normal size.)

2. Second jar: In the middle and on the right side of the picture mostly greenish-yellow thalli of Chlorella miniata and Protococcus anulatus are visible. (Somewhat larger than normal size.)

\section{PLATE III}

1. Third jar: (Somewhat smaller than normal size.)

2. Third jar: The stalactite on the right side of the picture is covered by dark, bark-like, greenish-black coating. For the sake of better demonstration this coating had been removed from part of the stalactite. In forming this coating mostly Synechococcus elongatus, Pseudanabaena tenuis and Oscillatoria agardhii took part. The olive green thalli visible on the entire picture are mostly Chlorella miniata, Gloeococcus schröterii and Protococcus anulatus. 

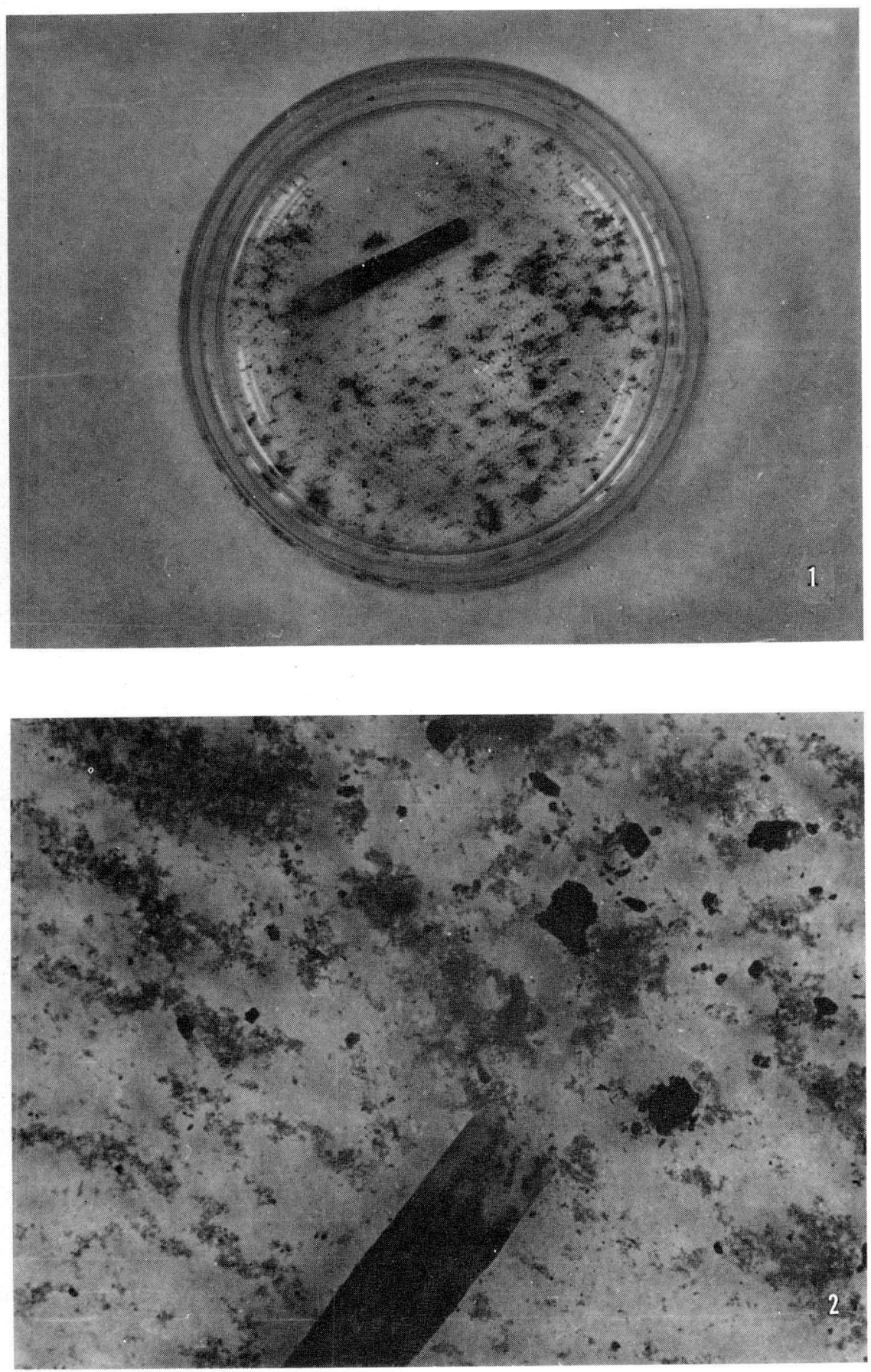

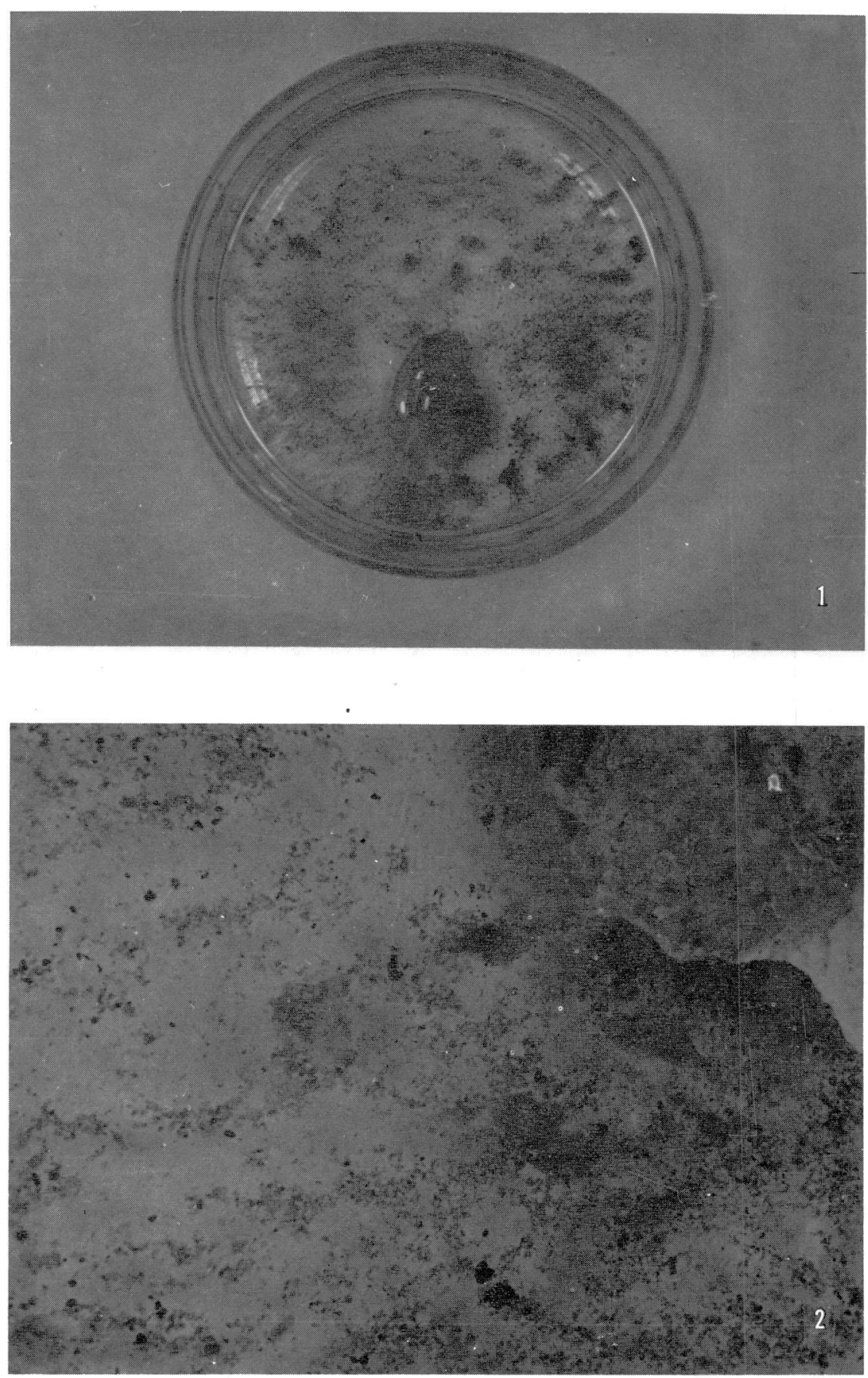

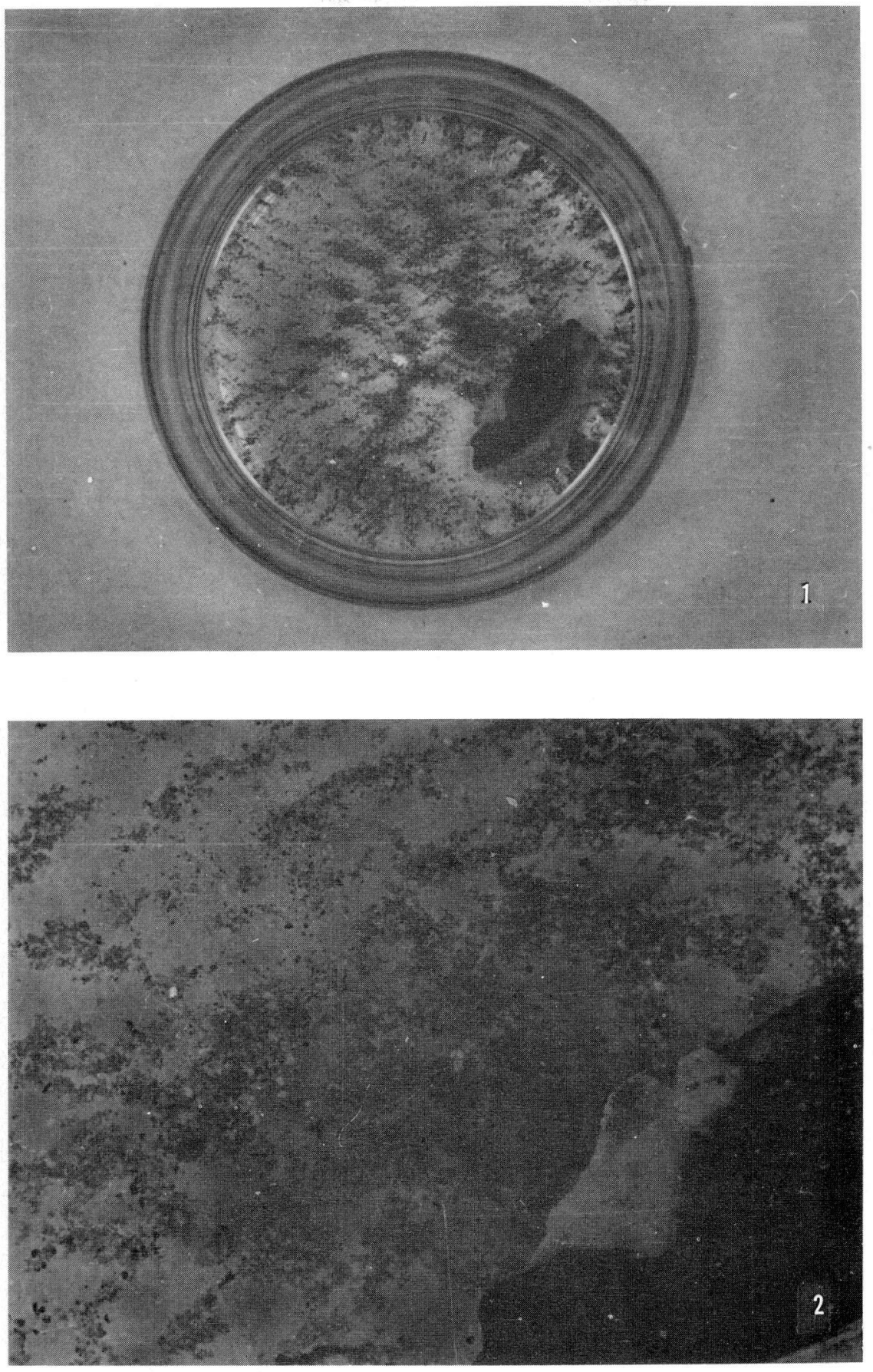